\title{
RASIO LEGIS PASAL 43 UNDANG-UNDANG NOMOR 20 TAHUN 2011 TERKAIT DENGAN IMPLEMENTASINYA
}

\author{
Landya Maria Simatupang, Imam Koeswahyono, Bambang Sugiri \\ Magister Kenotariatan Fakultas Hukum Universitas Brawijaya \\ Jl. MT. Haryono No. 169, Malang \\ landyasimatupang@gmail.com
}

\begin{abstract}
After the issuance of Law Number 20 Year 2011 on Flats (UU Rumah Susun)', problems arise when the implementation of the Act is what agreements / deeds can be used in terms of the requirements for implementing PPJB as stipulated in Article 43 of the House Law Arrange has not been fulfilled. Article 43 of the Flats Act allows developers to sell their apartment units, provided that they meet the requirements set forth in Article 43 of the Act (2). Furthermore, by using empirical juridical research methods, the authors further examine what is the legislative ratio of the arrangement of Article 43 of the Flats Act which must be obeyed by the developer. Then from the results of the study note that the legislation ratio of these provisions is in the framework of consumer protection.
\end{abstract}

Keywords: Sale and Purchase Agreement Agreement, Unit of Flats, Law No.20 Year 2011.

\begin{abstract}
Abstrak
Setelah terbitnya Undang-Undang Nomor 20 Tahun 2011 tentang Rumah Susun, muncul permasalahan saat implementasi UU dimaksud yaitu perjanjian/akta apa yang dapat dipergunakan dalam hal syarat-syarat untuk melaksanakan PPJB sebagaimana di atur dalam Pasal 43 UU Rumah Susun belum terpenuhi. Pasal 43 UU Rumah Susun mengijinkan pengembang untuk melakukan penjualan satuan rumah susun yang dibangunnya, asalkan memenuhi persyaratan - persyaratan yang diatur dalam Pasal 43 UU ayat (2) tersebut. Selanjutnya, dengan menggunakan metode penelitian yuridis empiris, penulis mengkaji lebih lanjut apa yang menjadi rasio legis pengaturan dari Pasal 43 UU Rumah Susun yang wajib dipatuhi oleh pengembang. Kemudian dari hasil penelitian tersebut diketahui bahwa rasio legis pengaturan ketentuan tersebut adalah dalam rangka perlindungan konsumen.
\end{abstract}

Kata Kunci : Perjanjian Pengikatan Jual Beli, Satuan Rumah Susun, UU No.20 Tahun 2011.

\section{A. Pendahuluan}

1. Latar Belakang Permasalahan

Istilah "satuan rumah susun" di Indonesia adalah bahasa dalam undangundang rumah susun, sedangkan dalam prakteknya rumah susun dikenal sebagai rumah sederhana yang diperuntukan bagi masyarakat ekonomi lapisan menengah ke bawah, yang karena keterbatasan lahan, dan demi efektifitas tanah, pemerintah merelokasi masyarakat ke rumah susun contohnya rumah susun tanah abang yang berlokasi di Jakarta Pusat, atau Rumah Susun Jatinegara Barat, peruntukannya adalah hunian. "Apartemen, kondominium, kondotel" adalah istilah yang dipakai untuk rumah susun peruntukan hunian oleh masyarakat ekonomi menengah ke atas bangunannya dibangun oleh pelaku pembangunan swasta, mewah dan memiliki banyak fasilitas - fasilitas yang nyaman. "Tempat Usaha berupa kios juga Perkantoran" merupakan Satuan Rumah Susun namun dari segi kegunaannya berjenis "Non Hunian". Berdasarkan uraian diatas sudah tersegmentasi masyarakat sebagai "Konsumen" atau "Pembeli" bahwa untuk Rumah Susun yang sederhana dibangun pemerintah untuk hunian masyarakat, sedangkan 
Apartemen, kondominium, kondotel, tempat usaha dibeli oleh masyarakat ekonomi menengah ke atas.

Berikut ini 4 pertimbangan yang menjadi dasar bagi calon pembeli: (Imam Koeswahyono, 2004)

1. Aksebilitasnya yakni lokasi apartemen mudah dicapai dengan kendaraan umum/pribadi, berdekatan dengan tempat bekerja dibanding dengan kalau berada diluarnya.

2. Harga per unit terjangkau oleh penghasilan calon pembeli dan dapat dibantu dengan fasilitas kredit pemilikan rumah susun/satuan rumah susun.

3. Keamanan dan kenyamanan yang juga menjadi penentu dalam memilih tempat hunian, karena akan memberikan rasa aman dan nyaman. Artinya tempat hunia sejuk, tidak bising serta bebas polusi.

4. Keuntungan yang akan diraih dalam jangka pendek maupun jangka panjang dibanding bunga deposito baik bagi pembeli nyata maupun untuk tujuan spekulasi.

Undang-undang Nomor 20 Tahun 2011 tentang Rumah Susun, mengatur tentang rumah susun dari mulai pengadaan tanah, perijinan, pemilikan juga mengenai pembentukan perhimpunan penghuninya, adalah semua menjadi inisiatif pengembang karenanya konsumen juga harus memperhatikan pengembang yang beritikad baik. Penulis dalam penelitian ini membahas mengenai hal "pemilikan rumah susun" yang mana Pelaku Pembangunan dapat memasarkan unit apartemen dan tempat usahanya dengan menandatangani Perjanjian Pengikatan Jual Beli dihadapan notaris hal itu diatur dalam Pasal 43 UU Rumah Susun.

Penulis tertarik untuk membahas latar belakang pembuatan pasal $43 \mathrm{UU}$ rumah Susun, mengapa pembuat undangundang begitu detail mengatur syarat yang harus dipenuhi pengembang, dan bagaimana pelaksanannya oleh pengembang dan konsumen, proyek pembangunan rumah susun hunian dan non hunian pemasarannya harus menyesuaikan dengan peraturan dalam Undang-undang Rumah Susun yang baru terbit menggantikan Undang-Undang Nomor 16 Tahun 1985, khusus Pasal 43 UU Rumah Susun mengatur tentang proses jual beli sebelum pembangunan rumah susun selesai.

Beberapa pengembang yang berencana membangun di tahun 2011 ragu tentang bagaimana pelaksanaan peraturan baru ini, pengembang mengalami kebingungan karena dari sisi bisnis pengembang dalam membangun apartemen dan tempat usaha, juga membutuhkan kepastian dana dari masyarakat, kepastian pembeli meski itu hanya berupa perikatan, hal ini diperlukan untuk kelancaran perputaran keuangan (cash flow) pengembang. Program Pemasaran yang dilakukan sebelum pembangunan dimulai, dengan cara launching product, para calon pembeli, sudah menyetorkan dana awal mereka, dengan menandatangani surat pemesanan, dan pembayaran booking fee, apabila berminat maka dilanjutkan dengan pelunasan dengan membayar tunai atau cara mohon kredit.

Selama Undang-Undang Nomor 16 Tahun 1985 tentang Satuan Rumah Susun berlaku para pelaku pembangunan melakukan penjualan rumah susun sebelum pembangunan selesai dengan cara menjual "gambar" berupa leaflet yang berisi gambar menarik yang menerangkan tentang produk atau berupa maket sebuah miniatur model bangunan yang akan dibuat untuk memvisualisasikan hasil rancangan bangunan dan dalam hal melakukan transaksi jual beli ini tentu saja memiliki kekuatan mengikat sebagaimana diatur dalam Pasal 1338 Kitab Undang-Undang Hukum Perdata, bahwa perjanjian akan menjadi undang-undang bagi para pihak, akan tetapi objek perjanjian yang masih belum terlihat wujudnya berpotensi dapat dibatalkan jika salah satu pihak menggugat.

\section{Kerangka Teori}

Teori hukum yang relevan untuk menganalisis secara kritis permasalahan pemilikan rumah susun ini adalah Teori Kepastian Hukum (Legal Certainty), kata kepastian yang bermakna sesuatu yang 
bersifat pasti, setelah hukum diundangkan dilaksanakan dengan pasti oleh negara, dan bagi yang melakukan pelanggaran dikenakan sanksi menurut hukum itu juga, pada penulisan jurnal ini penulis menggunakan teori Kepastian hukum yang dikutip oleh Bernard L. Tanya dalam buku Teori Hukum yaitu teori Gustav Radbruch yang menyatakan bahwa hukum tidak hanya sebagai tatanan formal dari normanorma, menurut Radruch mengemban nilai keadilan bagi kehidupan konkret manusia, dan untuk melengkapi keadilan dan finalitas itu, dibutuhkan kepastian dan teori kemanfaatan, untuk menganalisis permasalahan ini, teori Jeremy Bentham "Hukum adalah Penyokong Kebahagiaan" menurut Bentham apa yang sesuai digunakan atau selarasuntuk kepentingan individu adalah apa yang cenderung untuk memperbanyak kebahagian (Bernard L Tanya dkk, 2013). Karenanya hukum harus memberikan solusi lewat jalan "ukuran umum kebahagiaan" hak-hak individu dilindungi demi memehuni kebutuhankebutuhannya.

\section{Permasalahan}

Sebagaimana fenomena yang diuraikan di atas tentang maraknya pembangunan, penjualan dan pembelian satuan rumah susun dan adanya pengaturan dalam Pasal 43 UU Rumah Susun tentang persyaratan perikatan jual beli, penulis tertarik untuk meneliti apakah rasio legis pasal 43 Undang-Undang Rumah Susun Nomor 20 tahun 2011, dikaitkan dengan implementasinya pada dua perusahaan pengembang yang berkedudukan di Jakarta Selatan.

\section{Metode Penelitian}

Penulisan jurnal ini menggunakan metode penelitian yuridis empiris, dengan pendekatan yang bersifat yuridis sosiologis. Pendekatan ini mengkaji norma sebagaimana diatur dalam Pasal 43 UU Rumah Susun. Selain itu juga dipergunakan pendekatan konseptual dan wawancara. Lokasi penelitian di Kantor Pengembang PT.A dan PT. B yang keduanya merupakan pengembang ternama berkedudukan di Jakarta Selatan.
Hal ini didasarkan pada pertimbangan bahwa PT.A dan PT.B selaku pengembang melakukan penjualan sebelum pembangunan selesai dilaksanakan pasca UU rumah Susun dengan project Rumah Susun Hunian Apartemen C dan Rumah Susun Non Hunian Office S, dan bersedia di wawancara oleh Penulis.

\section{B. Hasil dan Pembahasan}

\section{Rasio Legis Pasal 43 UU Rumah Susun}

a. Urgensi Pengadaan Rumah Susun yang Merupakan Kebijakan Pemerintah Berdasarkan Undang-Undang Rumah Susun Nomor 20 Tahun 2011

Pengaturan baru yang penting bagi rumah susun dalam undang-undang rumah susun yang baru yaitu Undang-undang Nomor 20 Tahun 2011 bahwa sesuai dengan UUD 1945 Pasal $28 \mathrm{H}$ angka (2) Undang-Undang rumah susun ini diharapkan menjadi bentuk action negara dalam hal memberikan jaminan dan memperioritaskan pengadaan perumahan yang layak huni bagi masyarakat berpenghasilan rendah, yang saat ini kebutuhannya terpinggirkan, terkaithal itu maka nantinya pengaturan ini harus ditaati oleh para pengembang dan tidak ada celah hukum bagi pengembang untuk tidak bertanggung jawab. Bentuk action pemerintah untuk memenuhi Pasal $28 \mathrm{H}$ UUD 1945 adalah dengan adanya kebijakan pemerintah memberikan kemudahan bagi masyrakat berpenghasilan rendah untuk memiliki rumah susun yang layak huni, dengan cara fasilitas program bunga lunak khusus kredit pemilikan rumah susun sederhana (KPRS) bersubsidi, yang bertujuan untuk meringankan beban angsuran debitur, berupa subsidi selisih bunga, yang berarti pemerintah menanggung angsuran sebagian bunga KPRS yang ditetapkan oleh Bank.

Pada dasarnya urgensi pembangunan rumah susun sebagaimana diharapkan dalam pengaturan yang baru undangundang rumah susun adalah : (Naskah Akademik Rusun Panja Komisi V, Rabu 26 Mei 2010)

1. Dengan adanya penambahan penduduk 
di perkotaan dan ketersediaan tanah untuk pemukiman di perkotaan yang semakin meningkat, maka rumah susun menjadi solusi bagi pemenuhan kebutuhan perumahan.

2. Rumah susun harus dapat dihuni oleh setiap lapisan masyarakat baik itu masyarakat dengan penghasilan menengah keatas, atau menengah kebawah karenanya jenis rumah susun adalah rumah susun komersial bagi masyarakat berpenghasilan menengah ke atas yang dapat diperjual belikan, sebagai barang komoditas dan mengikuti mekanisme pasar, dengan Sistem Pengelolaan Rumah Susun yang semakin mantap. Pembangunan Rumah Susun pada prinsipnya memperhatikan pembangunan berkelanjutan di lingkungan sekitarnya, sehingga diharapkan mengurangi kesenjangan sosial. Dibuka peluang dalam undang-undang yang baru ini bagi badan usaha, koperasi maupun masyarakat untuk menyelenggarakan rumah susun sewa, khususnya bagi badan usaha, koperasi maupun masyarakat berpenghasilan menengah kebawah dengan berbagai insentif dari pemerintah.

\section{b. Landasan Filosofis}

Kelima sila dari Pancasila merupakan filosofis hukum di Indonesia, karenanya pembangunan rumah susun berdasarkan nilai-nilai dalam Pancasila. Sila Ketuhanan Yang Maha Esa, sila Kemanusiaan yang adil dan beradap dan sila persatuan Indonesia, menjadi dasar pembentuk undang-undang untuk membuat pengaturan penyelenggaraan rumah susun memenuhi nilai-nilai dari tiga sila dalam Pancasila, diharapkan pengaturan penyelenggaraan rumah susun yang baru kebutuhan pembangunan perumahan di Indonesia, tidak menimbulkan keresahan, atau kesenjangan sosial. Selanjutnya nilai kerakyatan untuk mencapai keadilan sosial dengan jalan musyawarah, dan sila keadilan sosial merupakan pandangan filosofis bangsa Indonesia yang menjelaskan bahwa bangsa Indonesia mengharuskan adanya kesempatan bagi semua segmen masyarakat memperoleh kebutuhan pemukiman yang layak, dengan lingkungan sehat, aman, serasi dan teratur.

Penulis menyimpulkan bahwa berdasarkan nilai-nilai dari Pancasila setiap orang berhak hidup layak lahir dan batin, bertempat tinggal yang layak, dilingkungan yang sehat, karena perumahan yang merupakan kebutuhan dasar manusia dapat memiliki peran dalam pembentukan watak serta kepribadian bangsa, karena rumah merupakan lembaga pendidikan untuk keluarga, hal ini merupakan tanggung jawab negara untuk melindungi, mengatur penyelenggaraan perumahan rumah susun yang layak bagi kehidupan yang sehat, aman, harmonis dan berkelanjutan di seluruh wilayah Indonesia, dan sebagaimana tercermin khususnya sila keadilan sosial, negara berkewajiban memenuhi kebutuhan tempat tinggal yang terjangkau bagi masyarakat berpenghasilan rendah.

\section{c. Landasan Sosiologis}

Secara sosiologis rumah menjadi tempat terbentuknya jati diri keluarga, dari kawasan pemukiman tempat tinggalnya menunjukan citra pada pemiliknya, kawasan pemukiman dimana tempat tinggal juga menunjukan status sosial tertentu seseorang. Persoalan yang baru muncul di masyarakat, bahwa perumahan tidak berfungsi lagi sebagai kebutuhan mendasar bagi manusia, perumahan kini diproduksi untuk dijadikan komoditas sektor privat yang didominasi oleh stakeholder yang menggunakan perumahan menjadi komoditas utamanya untuk meraih keuntungan. Para stakeholder tersebut contohnya pengembang, kontraktor, produsen bahan bangunan, dan penyedia perumahan seperti pemberi kredit rumah, investor, spekulan tuan tanah dan pemilik rumah itu sendiri, pada akhirnya harga jual yang ditanggung konsumen menjadi tinggi. Harga tanah menjadi mahal, karena ketersediaan lahan pertanahan semakin sempit di perkotaan, akibat pesatnya perkembangan kota, akibatnya masyarakat 
berpenghasilan rendah tidak mampu berdaya beli (Naskah Akademik Rumah Susun Panja Komisi V). Undang-undang rumah susun yang baru lebih berorientasi kepada kepentingan seluruh lapisan masyarakat secara berkeadilan sosial, peningkatan serta pengembangan dibidang perumahan dan rumah susun yang profesional. Kondisi sosiologis bahwa telah terjadi kesenjangan antar wilayah mengakibatkan terjadinya pusat pertumbuhan yang tidak merata, pusat pulau Jawa lebih mempunyai peluang dalam hidup dan penghidupan yang berimplikasi pada penyelenggara rumah susun hal ini berakibat pada arus imigrasi ke kota tidak diimbangi dengan penyediaan perumahan, konsentrasi investasi di kota besar justru mendesak keluar pemukiman untuk masyarakat berpenghasilan rendah (MBR), Menyusutnya peluang penghidupan di pedesaan (Naskah Akademik Panja Komisi V).

\section{d. Landasan Yuridis}

Landasan yuridis dalam pembuatan Undang-Undang Rumah Susun Nomor 20 Tahun 2011, adalah Undang-Undang Dasar 1945 Pasal $28 \mathrm{H}$, yang maknanya bahwa undang-undang dasar mengamanatkan setiap orang berhak hidup sejahtera, bertempat tinggal dan memperoleh lingkungan hidup yang baik, sehat serta berhak memperoleh pelayanan kesehatan, amanat dalam Undang-Undang Dasar 1945 Pasal $28 \mathrm{H}$ merupakan pengaturan dasar menekankan tentang kesejahteraan setiap orang lahir dan batin, bertempat tinggal layak di lingkungan yang sehat. Landasan Yuridis selanjutnya Undang-Undang Nomor 39 Tahun 1999 tentang Hak Asasi Manusia Pasal 40. Kedua undang-undang ini digunakan sebagai dasar pengaturan bagi pemenuhan kebutuhan dasar manusia akan rumah, baik dalam bentuk rumah tinggal maupun rumah susun (Naskah Akademik Rumah Susun Panja Komisi V).

Penyusunan Rancangan undangundang dilakukan dengan memperhatikan beberapa hukum positif yang akan banyak memberikan warna pada substansinya. Penyusunan naskah akademis juga melaksanakan review bagi peraturan perundang-undangan yang terkait dengan undang-undang rumah susun diantaranya Undang-undang Nomor 5 Tahun 1960 tentang Pokok-Pokok Agraria, Undang-undang Nomor 4 Tahun 1996 tentang Hak Tanggungan Atas Tanah, beserta Benda-benda yang berkaitan dengan Tanah, Undang-undang Nomor 42 Tahun 1999 Tentang Fidusia, Undangundang Nomor 28 Tahun 2002 tentang Bangunan Gedung, Und ang-und ang nomor 32 Tahun 2004 tentang Pemerintah Daerah,. Undang-undang nomor 32 Tahun 2009 Tentang Perlindungan dan Pengelolaan Lingkungan Hidup, dan Undang-undang Nomor 26 Tahun 2007 tentang Penataan Ruang.

\section{e. Pasal 43 UU Rumah Susun}

Sebagaimana bahasan penulis dalam Jurnal ini adalah menulis mengenai rasio legis Pasal 43 terkait dengan implementasi Perjanjian Pengikatan jual Beli berdasarkan Undang undang Nomor 20 Tahun 2011, bahwa syarat Perjanjian Pengikatan Jual Beli wajib sebagaimana diatur dalam Pasal 43 Undang-Undang Nomor 20 Tahun 2011, penulis mengutip latar belakang pembuat undang-undang nomor 20 Tahun 2011 tentang rumah susun dalam naskah akademik Rumah Susun Panja Komisi V Naskah Akademik Rumah Susun Panja Komis V, Rabu 26 Mei 2010 hal 58.

dalam petikan paragrap di dalam naskah akademik satuan rumah susun, mengulas tentang syarat penjualan satuan rumah susun yang diatur dalam Pasal 18 ayat (1) Undang-Undang Rumah Susun Nomor 16 Tahun 1985, bahwa syarat pengembang menjual setelah mendapatkan ijin layak huni dan sertipikat hak milik atas satuan rumah susun. Sertipikat hak milik atas satuan rumah susun dan ijin layak huni merupakan produk perijinan terakhir untuk pembangunan rumah susun, dan untuk memperoleh perijinan itu bangunan harus sudah dalam keadaan siap di huni, hal ini menyulitkan bagi pengembang, karena dalam membangun pengembang 
membutuhkan dana, sumber dana antara lain modal dasaryang sudah disetor oleh para pemegang saham ke dalam perseroan, dana dari investor asing atau dalam negeri yang dengan cara melakukan Joint Operation (JO), dana dari fasilitas kredit konstruksi dan dana yang berasal dari konsumennya, dana-dana ini bila mengalir akan membantu perputaran keuangan pengembang selama pengembang melaksanakan pembangunan rumah susun, hingga selesai tepat pada waktunya.

Surat Keputusan Menteri Perumahan Rakyat Nomor 11/KPTS/1994 tentang Perjanjian Pengikatan Jual Beli Satuan Rumah Susun sebelum rumah susun bersangkutan selesai pembangunan konstruksinya. Keputusan Menteri perumahan rakyat ini untuk mengijinkan terjadinya "Jual Beli Pendahuluan" sebelum bangunan selesai dibangun pengembang dan konsumen dapat melaksanakan perjanjian pengikatan jual beli, hal ini tentu saja bertentangan dengan Pasal 18 ayat (1) Undang-Undang Nomor 16 tahun 1985, dan surat keputusan menteri perumahan rakyat ini dimanfaatkan menjadi celah hukum bagi pengembang nakal/fiktif untuk melakukan pengikatan jual beli satuan rumah susun demi menarik dana segar dari masyarakat.

Selanjutnya dalam naskah akademik rumah susun Naskah Akademik Rumah Susun Panja Komisi V Rabu, 26 Mei 2016 hal 65-66 penulis mengutip paragrap tentang perjanjian pengikatan jual beli rumah susun.

Dalam kutipan paragrap ini, pembuat undang-undang menyoroti tentang perlindungan konsumen bagi konsumen yang melaksanakan perjanjian pengikatan jual beli satuan rumah susun perdana, sebagaimana diatur dalam kepmenpera yaitu memiliki IMB terlebih dahulu baru diperbolehkan melakukan perjanjian pengikatan jual beli apabila pengembang telah memiliki IMB, namun hal itu sering diabaikan, akibatnya merugikan konsumen. Pembuat undang-undang menegaskan perlu ada sanksi pidana yang berat untuk pengembang-pengembang yang tidak bertanggung jawab, yang berani melaksanakan perjanjian pengikatan jual beli disaat lokasi pembangunan belum ada kegiatan pembangunan sama sekali, akan tetapi pengembang sudah menarik uang konsumen, yang pada akhirnya merugikan konsumen. Pasal 43 Undang-Undang Rumah Susun Nomor 20 Tahun 2011, mengatur ketentuan tentang syarat-syarat Perjanjian Pengikatan Jual Beli, dan secara tegas diatur lagi dalam pasal pelanggaran yang diatur dalam Pasal 98, Pasal 110 undang-undang nomor 20 Tahun 2011 yang dengan tegas sanksi pidana penjara dan denda bunyi pasal 110 .

Sebagaimana diuraikan dalam kutipan paragrap naskah akademik satuan rumah susun bahwa perlindungan konsumen adalah maksud dari bunyi Pasal 43 Undang-Undang Satuan Rumah Susun Nomor 20 tahun 2011, bahwa pengembang-pengembang fiktif/nakal yang tidak bertanggung jawab hanya menerima dana dari masyarakat melalui pelaksanaan Perjanjian Pengikatan Jual Beli, namun selanjutnya tidak melaksanakan tanggung jawabnya selaku pengembang dengan penyerahan unit yang tidak kunjung diserahkan atau dengan tak kunjung terbitnya sertipikat hak milik rumah susun sebagai bukti pemilikan konsumen selaku pembeli.

Dalam penjelasan Pasal 43 UndangUndang Rumah Susun Nomor 20 Tahun 2011 ayat (1), ayat (2), huruf (a), huruf (b), dan huruf (c) dinyatakan "cukup jelas' sedangkan pada huruf (d) dan huruf (e) penjelasan pasal 43 undang-undang rumah susun nomor 20 tahun 2011.

Pada kesimpulannya Pasal 43 Undang-Undang Rumah Susun Nomor 20 Tahun 2011, mengatur syarat-syarat mengenai penjualan satuan rumah susun sebelum bangunan selesai dilakukan dapat dilaksanakan oleh Pengembang, akan tetapi sebelum melaksanakan penjualan wajib memenuhi syarat-syarat terlebih dahulu diantarannya memiliki hak atas tanah, IMB, sarana dan prasarana fasilitas umum, keterbangunan $20 \%$ dan hal yang diperjanjikan, syarat-syarat ini bila tidak dipenuhi dinyatakan pelanggaran dan 
dikenakan sanksi pidana berupa kurungan dan denda yang tidak sedikit jumlahnya, persyaratan ini untuk melindungi hak-hak konsumen dari nakalnya para pengembang yang tidak bertanggungjawab, menarik dana dari masyarakat akan tetapi tidak menyelesaikan pembangunan sesuai waktu yang dijadwalkan, tidak sanggup menyelesaikan perijinan-perijinan.

\section{Implementasi Pasal 43 UU Rumah Susun pada PT.A dan PT.B (Dua Perusahaan Pengembang)}

Pengembang PT.A dan PT.B berkedudukan di Jakarta Selatan, membangun proyek apartemen "C" dan Perkantoran "S" yang keduanya berlokasi di Jakarta Selatan, penulis sengaja menyamarkan nama pengembang dan nama proyek, karena data dipergunakan hanya untuk kepentingan penelitian. Pengembang PT.A, menurut hasil wawancara penulis dengan legal pengembang PT.B, penulis memperoleh hasil bahwa PT.A memang melakukan Perjanjian Pengikatan Jual Beli dengan konsumennya objek perjanjiannya apartemen $\mathrm{C}$, konsumennya perorangan. Tahap yang dilakukan oleh Pengembang PT.A adalah Surat Pemesanan, Konfirmasi pemesanan, dan Perjanjian Pengikatan Jual Beli. Perjanjian yang dibuat oleh PT.A adalah perjanjian dibawah tangan, pada tahap Surat Pemesanan ada pembayaran booking fee, dan jelas unit yang akan dibeli, dilanjutkan dengan penandatanganan konfirmasi pemesanan yang konstruksi perjanjiannya menyerupai dengan perjanjian pengikatan jual beli, bahwa dalam konfirmasi pemesanan jelas dinyatakan bahwa akan ada pembayaran sebesar $40 \%$ yang langsung dicicil kepada pengembang, juga dalam konfirmasi pemesanan dinyatakan bahwa konfirmasi pemesanan ini ditandatangani karena belum memenuhi syarat dalam pasal 43 ayat (2), dan apabila syarat dalam pasal 43 ayat (2) terutama keterbangunan 20\% menurut keterangan legal pengembang dilaksanakan perjanjian pengikatan jual beli setelah tahap 20\% keterbangunan itu sudah terpenuhi, dan semua perjanjian dibuat secara dibawah tangan.
Legal pengembang PT.A juga menjelaskan bahwa persyaratan baru ini, membuat perputaran keuangan menjadi melambat, yang biasanya setelah menandatangani PPJB, dana 40\% sudah bisa dicairkan melalui fasilitas kredit, akan tetapi saat diundangkan Pasal 43 ayat (2) ini, dana 40\% yang dibayarkan konsumen dengan menandatangani konfirmasi pemesanan, dibayarkan perbulan langsung ke pengembang, hal ini karena perbankan hanya mengakui PPJB sebagai bentuk bukti telah terjadi jual beli antara pengembang dan konsumen, konfirmasi pemesanan tidak diakui Perbankan sebagai alat bukti telah terjadi jual beli, dan pengembang PT.A melalui hasil wawancara juga menyampaikan bahwa aturan ini menghambat bisnis pengembang.

Pembuatan Konfirmasi Pemesanan yang menyerupai Perjanjian Pengikatan Jual Beli menurut pendapat penulis adalah cara PT.A menyimpang dari Pasal 43 ayat 2 butir (d) UURS Nomor 20 Tahun 2011, yang dilakukan secara diam-diam, bahwa syarat keterbangunan $20 \%$, yang belum terpenuhi. Penyimpangan/pengabaian ini membuat perjanjian menjadi tidak memiliki kepastian hukum dalam hal ini kepastian hubungan hukum antara penjual dan pembeli, "konfirmasi pemesanan " dengan membayarkan $30 \%$ dari harga jual bukanlah "memesan" seharusnya hubungan hukum mereka adalah "jual beli" dan penulis berpendapat norma disimpangi/diabaikan karena menurut pengembang norma tidak memberikan manfaat hukum, sebagaimana dikemukakan Jeremy Bentham dalam teorinya kemanfaatan hukum yang harus memberikan kebahagiaan, karena sifat manusia cenderung mencari kebahagiaan.

PT.B adalah pengembang kedua yang penulis wawancara, mengenai keterpenuhan syarat perjanjian pengikatan jual beli proyek Perkantoran $\mathrm{S}$ yang terletak di Jakarta Selatan adalah bangunan milik PT.B yang di jual di tahun 2012 dalam keadaan belum memenuhi syarat dalam pasal 43 ayat (2) yaitu keterbangunan $20 \%$, namun pihak 
pengembang tetap membuat menjual satuan rumah susun non hunian (office) yang dibeli oleh konsumennya yaitu perseroan yang membeli kantor yang menjadi asset perseroan, dan dengan alasan itu maka pengembang dan konsumen melakukan perjanjian pengikatan jual beli secara notariil. Sebagaimana diatur dalam pasal 43 UURS Nomor 20 Tahun 2011, keduanya melakukan pengenyampingan Pasal 43 ini di dalam PPJB yang dibuat dihadapan notaris, dan berjanji untuk tidak saling menggugat dan menyelesaikan semua perselisihan secara musyawarah, pada akhirnya kembali kepada asas perjanjian yaitu asas Pacta Sunt Servanda yang disimpulkan dalam Pasal 1338 Kitab Undang-Undang Hukum Perdata bahwa hakim atau pihak ketiga harus menghormati substansi perjanjian yang dibuat dan ditaati oleh para pihak. Penulis berpendapat apa yang dilakukan oleh Pengembang PT.B merupakan penyimpangan/pengabaian yang dilakukan secara tegas, para pihak yang berjanji untuk tidak saling menggugat sebetulnya membatasi perlindungan konsumen, bahwa apabila dikemudian hari ada permasalahan diantara para pihak, maka konsumenlah yang paling dirugikan, karena sudah terikat pada klausula "tidak saling menggungat".

Pada akhirnya, kedua pengembang membuat perjanjian pengikatan jual beli satuan rumah susun dengan mengabaikan Pasal 43 ayat 2 huruf (d), yang akibat hukumnya adalah perjanjian menjadi batal demi hukum, dengan demikian apa yang dibuat oleh para pihak menjadi tidak memiliki kepastian hukum, dan pengabaian Pasal 43 ayat 2 huruf (d) adalah bukti bahwa norma tidak memberikan kemanfaatan hukum bagi pengembang.

\section{Simpulan}

Berdasarkan uraian di atas, maka dapat diambil kesimpulan bahwa dasar Rasio Legis UU Rumah Susun, yang penulis dapatkan dari naskah akademik undangundang rumah susun pada kesimpulannya adalah bermaksud untuk fokus pada pengadaan rumah susun bagi masyarakat berpenghasilan rendah, demi mengatasi arus urbanisasi, pertambahan penduduk di perkotaan, dan pembiayaan didapatkan dari $20 \%$ pendapatan pengembang swasta yang membangun rumah susun untuk masyarakat berpendapatan menengah ke atas. Rasio Legis pembentukan Pasal 43 UU Rumah Susun, yang mana tujuan pokok dari pembuat undang-undang adalah untuk perlindungan konsumen dengan mengatur sanksi yang berat bagi pengembang. UU No. 16 Tahun 1985 tentang Rumah Susun mengamanatkan Jual Beli Rumah Susun dapat dilakukan setelah adanya ijin layak fungsi dan telah terbitnya Sertipikat Hak Milik Satuan Rumah Susun, akan tetapi pengembang melakukan penjualan pendahuluan dan mengabaikan UU No.16 Tahun 1985, dan pemerintah mengeluarkan Keputusan Menteri Perumahan Rakyat Nomor: 11/KPTS/1994, Tanggal 17 Nopember 1994 tentang Pedoman Perikatan Jual Beli Satuan Rumah Susun, terbitnya Kep.Menpera ini demi melindungi konsumen agar pengembang tidak sembarangan membuat perjanjian pengikatan jual beli yang dikenal dengan "perjanjian sepihak". Namun Kep.Menpera ini dianggap oleh pembuat Undang-undang Rumah Susun yang baru memiliki kelemahan hukum, yaitu bertentangan dengan isi UURS No.16 Tahun 1985 dan kurangnya sanksi atas pelanggaran yang dilakukan pengembang, karenanya terbit kini Pasal 43 mengenai syarat PPJB, Pasal 98 tentang Larangan, dan Pasal 110 tentang Sanksi pidana dan sanksi administrasi.

Di akhri tulisan ini, penulis memberikan saran bahwa untuk Pembuat undang-undang adalah ideal membuat peraturan dengan syarat dan sanksi yang berat, demi adanya keadilan, kemanfaatan dan keadilan yang mewujudkan keteraturan di dalam masyarakat. Terbentuknya Pasal 43 UURS Nomor 20 Tahun 2011 adalah untuk perlindungan konsumen, akan tetapi untuk pengembang yang melakukan usaha dibidang pembangunan properti belum mampu melaksanakan syarat-syarat sebelum pelaksanaan 
perjanjian pengikatan jual beli satuan rumah susun, alasan utama adalah perputaran dana, dana dari konsumen masih sangat diharapkan untuk kelancaran keuangan perusahaan dalam melaksanakan pembangunan, saran dari hasil penelitian ini adalah adanya perubahan syarat yang lebih ringan dari syarat yang sekarang berlaku, agar tujuan perlindungan konsumen tetap dapat tercapai, meskipun kenyataannya di negara berkembang seperti Indonesia belum mampu untuk sungguh-sungguh menerapkan perlindungan konsumen, mengingat kondisi keuangan perusahaan.

\section{DAFTAR PUSTAKA}

Hutagalung,Arie S. (2007) Kondominium Dan Permasalahannya edisi revisi, Depok: Badan Penerbit Fakultas Hukum Universitas Indonesia.

Sutedi, Adrian. (2012) Peralihan Hak Atas Tanah, cetakan kedua Jakarta: PT. Sinar Grafika.

Tanya, Bernard L. (2013) Teori Hukum Strategi Terbit Manusia Lintas Ruang dan Generasi, Cetakan IV, edisi revisi, Yogyakarta: Genta Publishing.

Leks, Eddy M. (2016) Panduan Praktis Hukum Properti, Jakarta: PT.Gramedia Pustaka.

Aplikasi, Erwin Kalolo. (2004) Hukum Dalam Bisnis Properti di Indonesia, Yogyakarta: Ombak.

Koeswahyono, Imam (2004) Hukum Rumah Susun Suatu Bekal Pengantar Pemahaman, Malang.

Koeswahyono, Imam (1995) Konsepsi Hak Milik Atas Satuan Rumah Susun dalam Hukum Agraria, Setara Press: Cetakan Pertama Januari.

Santoso, Urip (2014) Hukum Perumahan Cetakan Pertama, Jakarta: Kencana.

Satrio, J. (1995) Hukum Perikatan, Perikatan Yang Lahir dari Perjanjian, Bandung: PT.Citra Aditya Bakti.

Wijaya, Andika. (2017) Hukum Bisnis Properti di Indonesia, Jakarta: Grasindo. 